\title{
FTO Gene Polymorphisms Contribute to the Predisposition and Radiotherapy Efficiency of Nasopharyngeal Carcinoma [Retraction]
}

Xiao F, Zhou J. Pharmgenomics Pers Med. 2021;14:12391245.

At the authors request, the Editor and Publisher of Pharmacogenomics and Personalised Medicine wish to retract the published article. The authors have advised that despite the research being approved and authorized by the Ethics Committee of the School of Nursing of Chongqing Medical University, it also needed to be approved and authorized by the Ethics Committee of Chongqing Medical University. However, the authors were not aware of this requirement and failed to acquire the appropriate authorization prior to commencement of the study and have requested to retract the article.

The authors wish to apologise for this error.

Our decision-making was informed by our policy on publishing ethics and integrity and the COPE guidelines on retraction.

The retracted article will remain online to maintain the scholarly record, but it will be digitally watermarked on each page as "Retracted".

\section{Publish your work in this journal}

Pharmacogenomics and Personalized Medicine is an international, peer-reviewed, open access journal characterizing the influence of genotype on pharmacology leading to the development of personalized treatment programs and individualized drug selection for improved safety, efficacy and sustainability. This journal is indexed on the American Chemical Society's Chemical Abstracts Service (CAS). The manuscript management system is completely online and includes a very quick and fair peer-review system, which is all easy to use. Visit http://www.dovepress.com/testimonials.php to read real quotes from published authors. 